\title{
Dermatologia, Wenerologia i Alergologia, Sopot 2014
}

W dniach 5-6 września 2014 roku w hotelu Sheraton w Sopocie odbyła się dwudniowa konferencja "Dermatologia, Wenerologia i Alergologia 2014", której organizatorem była Klinika Dermatologii, Wenerologii i Alergologii Gdańskiego Uniwersytetu Medycznego (GUM). Konferencja zgromadziła ponad 400 uczestników z całej Polski, głównie lekarzy dermatologów, jak również pediatrów, onkologów, alergologów i lekarzy rodzinnych. Przewodniczącym Komitetu Naukowego i Komitetu Organizacyjnego był prof. Roman Nowicki, kierownik Kliniki Dermatologicznej GUM.

Wybitni i doświadczeni wykładowcy oraz przedstawiciele gdańskiej Kliniki omówili najświeższe doniesienia na temat rozpoznawania i leczenia chorób alergicznych skóry, chorób pęcherzowych, grzybic, łuszczycy oraz nowotworów skóry. Poruszony został również problem diagnostyki i terapii chorób przenoszonych drogą płciową - tak kontrowersyjny w dobie trwających aktualizacji polskich wytycznych.

Konferencja rozpoczęła się w piątek, 5 września. Na wstępie prof. Roman Nowicki powitał wszystkich uczestników (ryc. 1.). Następnie otwarcia spotkania dokonał prorektor GUM ds. nauki, prof. Tomasz Bączek.

Obrady konferencji zostały ujęte w 9 sesji tematycznych, obejmujących najważniejsze problemy z praktyki dermatologicznej. Na zakończenie większości wykładów odbywał się quiz interaktywny, co pozwalało wszystkim słuchaczom aktywnie uczestniczyć w konferencji i sprawdzić swoją wiedzę z zakresu dermatologii. W obu dniach wykłady w sesjach poprzedzone były warsztatami. W piątek były



Rycina I. Profesor Roman Nowicki otwierający konferencję to warsztaty dermatoskopowe, a w sobotę warsztaty na temat terapii podstawowej $\mathrm{w}$ atopowym zapaleniu skóry, ze szczególnym uwzględnieniem mokrych opatrunków. O dużym zainteresowaniu warsztatami może świadczyć pełna sala wykładowa w sopockim hotelu Sheraton oraz liczne pytania do wykładowców.

Konferencję otworzył wykład inauguracyjny pod tytułem "Łysienie androgenowe - co nowego" prof. Lidii Rudnickiej, kierownik warszawskiej Kliniki Dermatologicznej (ryc. 2.), która dziękując za zaproszenie do udziału w konferencji, podkreśliła swoje uznanie dla holistycznego i humanistycznego podejścia do medycyny, jakie reprezentuje prof. Roman Nowicki. Po tak miłym wstępie mieliśmy możliwość usłyszeć o roli trichoskopii w rozpoznawaniu łysienia oraz o różnych metodach terapeutycznych. Najwięcej miejsca poświęcono terapii finasterydem, zarówno w aspekcie jego skuteczności, jak i bezpieczeństwa. Postęp technik diagnostycznych w łysieniu androgenowym jest większy niż postęp w leczeniu - to konkluzja wykładu, niezbyt optymistyczna dla pacjentów. Pierwszą sesję interaktywną "Łuszczyca 2014" wypełnił wykład prof. Adama Reicha (ryc. 3.) z Wrocławia, który obfitował $\mathrm{w}$ najnowsze doniesienia $\mathrm{z}$ piśmiennictwa na temat możliwości terapeutycznych łuszczycy u dzieci, u kobiet w ciąży, u pacjentów HIV-dodatnich oraz łuszczycy płytek paznokciowych. Coraz liczniejsze i powszechniej dostępne opcje leczenia systemowego łuszczycy stawiają nowe wyzwania przed lekarzami sprawującymi opiekę nad chorymi zarówno w warunkach ambulatoryjnych, jak i szpitalnych.

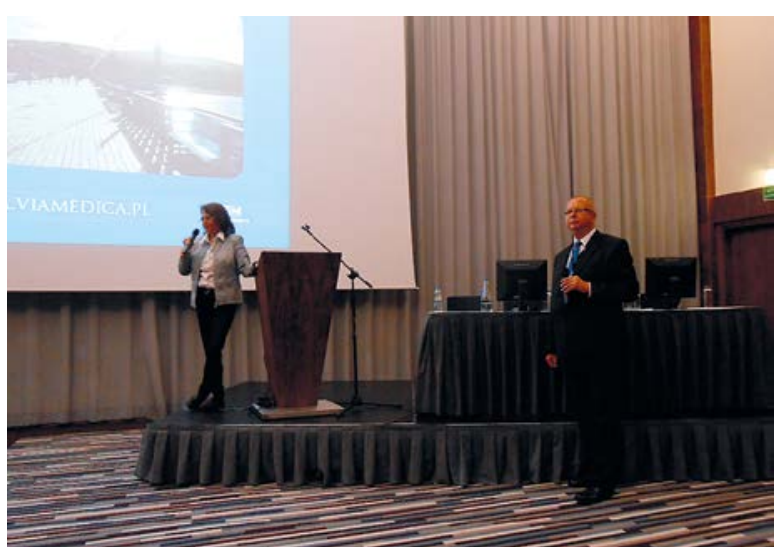

Rycina 2. Profesor Lidia Rudnicka rozpoczynająca konferencję wykładem na temat łysienia androgenowego 
Sesję II „Trądzik w codziennej praktyce” otworzył wykład prof. Andrzeja Kaszuby, w którym zostały przedstawione główne tezy najnowszego konsensusu Polskiego Towarzystwa Dermatologicznego dotyczącego patogenezy i leczenia trądziku. Różny stopień nasilenia zmian trądzikowych u poszczególnych pacjentów stawia przed lekarzem dermatologiem konieczność wyboru najodpowiedniejszej, adekwatnej do obrazu klinicznego metody leczenia, która powinna uwzględnić wiek i płeć pacjenta, indywidualne problemy psychiczne, żywieniowe czy pielęgnacyjne. Warunkiem dobrego wyniku terapeutycznego jest współpraca pacjenta z lekarzem, dokładna realizacja zaproponowanej metody leczenia oraz kontrola występowania możliwych działań ubocznych. Często konieczne jest prowadzenie terapii skojarzonej, łączącej metody leczenia ogólnego i miejscowego z zastosowaniem metod zabiegowych w celu likwidacji blizn potrądzikowych. Drugi wykład w tej sesji wygłosiła doc. Wioletta Barańska-Rybak z gdańskiej Kliniki Dermatologicznej. Usłyszeliśmy w nim o nowych możliwościach terapeutycznych w trądziku różowatym. Spośród przedstawionych nowości zwrócono uwagę na winian brimonidyny (agonista receptora $\alpha 2$-adrenergicznego), który w postaci 3\% żelu jest od niedawna stosowany w objawowym leczeniu rumienia twarzy, oraz na $1 \%$ iwermektynę w kremie, której efekt terapeutyczny opiera się na hamowaniu produkcji cytokin prozapalnych - TNF- $\alpha$ oraz IL-1b. W prezentacji przedstawione zostały mechanizmy działania obu leków, wyniki badań klinicznych potwierdzających ich skuteczność oraz obserwowane działania niepożądane.

W sesji III „Choroby pęcherzowe i choroby tkanki łącznej” usłyszeliśmy trzy wykłady. W części poświęconej chorobom pęcherzowym prof. Cezary Kowalewski z Warszawy przedstawił polski konsensus diagnostyczno-terapeutyczny dotyczący pęcherzycy, a prof. Katarzyna Woźniak podsumowała najnowsze doniesienia na temat rozpoznawania i leczenia pemfigoidu na podstawie konsensusu europejskiego, zapowiadając równocześnie powstanie w najbliższym czasie konsensusu polskiego. W obu prezentacjach dokonano bardzo przejrzystego podsumowania wszystkich aktualnych możliwości terapeutycznych tych trudnych schorzen. Zwrócono również uwagę na potrzebę dokładnego wywiadu $\mathrm{u}$ pacjentów $\mathrm{z}$ rozpoznaniem chorób pęcherzowych pod kątem stosowanych w ciągu ostatnich 12 miesięcy leków mogących prowokować zmiany skórne, takich jak niektóre antybiotyki (penicyliny, cefalosporyny, chinolony), inhibitory ACE, $\beta$-adrenolityki, D-penicylamina, spironolakton, furosemid czy leki antypsychotyczne. Rozpoznanie polekowego charakteru schorzenia pozwala na eliminację jego przyczyny i uzyskanie remisji zmian skórnych. W trzecim

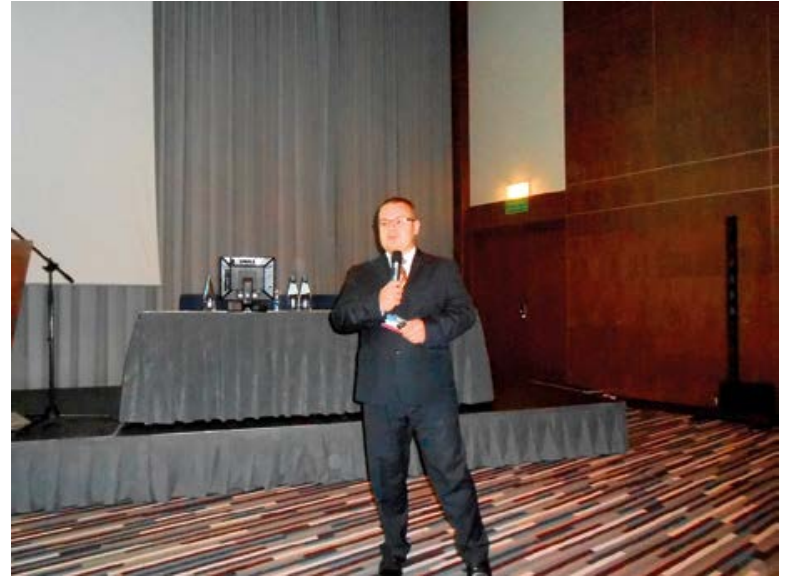

Rycina 3. Profesor Adam Reich podczas sesji interaktywnej poświęconej łuszczycy

wykładzie w tej sesji doc. Aneta Szczerkowska-Dobosz z Kliniki Dermatologicznej w Gdańsku przedstawiła patomechanizm oraz możliwości leczenia lipoatrofii nabytych, ze szczególnym uwzględnieniem przypadków zaniku tkanki tłuszczowej w następstwie zapalenia tkanki podskórnej w przebiegu twardziny, zapalenia skórno-mięśniowego czy tocznia rumieniowatego. W lipoatrofii towarzyszącej chorobom tkanki łącznej istotne znaczenie ma zapobieganie zanikom tkanki tłuszczowej poprzez szybkie rozpoznanie i wdrożenie leczenia choroby w jej fazie aktywnej, aby nie dopuścić do rozwoju bliznowacenia i powstania zmian atroficznych. Prelegentka omówiła możliwości rekonstrukcji wolumetrycznej ognisk lipoatrofii za pomocą własnej tkanki tłuszczowej, kwasu polimlekowego, hydroksyapatytu wapnia czy kwasu hialuronowego. Poprawa wyglądu ma olbrzymie znaczenie dla chorych, ponieważ zmniejsza ich stygmatyzację i dysfunkcję psychospołeczną.

Sesję IV - alergologiczną - rozpoczął wykład konsultanta krajowego w dziedzinie alergologii prof. Jerzego Kruszewskiego „Postępy w rozumieniu patogenezy chorób alergicznych”. W wykładzie przedstawiono m.in. różne mechanizmy anafilaksji, w tym rolę kofaktorów, takich jak wysiłek, niesteroidowe leki przeciwzapalne czy alkohol, w rozwoju reakcji anafilaktycznych. Duża część wykładu była poświęcona badaniom nad poszukiwaniem nowych leków w schorzeniach alergicznych, szczególnie terapii biologicznych. Autor przedstawił doniesienia na temat możliwości rozszerzenia wskazań do leczenia omalizumabem. Poza astmą oskrzelową lek okazał się skuteczny w niektórych odmianach pokrzywki, $\mathrm{w}$ alergii pokarmowej oraz $\mathrm{w}$ uogólnionych reakcjach anafilaktycznych. Takie spektrum wskazań do omalizumabu wiąże się z poznaniem nowych mechanizmów działania tego leku - nie tylko me- 
chanizm anty-IgE, lecz także stabilizacja komórek tucznych. Coraz więcej badań potwierdza też, jak ważnym mediatorem groźnych dla życia reakcji anafilaktycznych jest czynnik aktywujący płytki (ang. platelet-activating factor - PAF). Jego stężenia najlepiej korelują z ciężkością tych reakcji. Surowicze stężenie PAF zależy w głównej mierze od enzymu - acetylohydrolazy PAF, który jest zdolny do konwersji aktywnego PAF do postaci nieaktywnej (lyso-PAF). Rozpoczęto już badania na zwierzętach, których celem jest opracowanie metody substytucji tego enzymu w przypadkach jego niedoboru. W kolejnym wykładzie prof. Magdalena Czarnecka-Operacz z Poznania przedstawiła immunologiczne reakcje zapalne w alergicznych chorobach skóry. W licznych wątkach wykładu poruszono m.in. problem mechanizmów tolerancji immunologicznej pod wpływem immunoterapii swoistej, rolę komórek dendrytycznych w odpowiedzi Th2, a z aspektów praktycznych - możliwość zastosowania omalizumabu w terapii atopowego zapalenia skóry. W trzecim wykładzie tej sesji prof. UJ Radosław Śpiewak podjął się trudnego zadania odpowiedzi na pytanie, czy wyprysk atopowy jest chorobą alergiczną. Profesor Śpiewak podkreślił, że wyprysk atopowy jest schorzeniem bardzo zróżnicowanym pod względem mechanizmu powstawania zmian i udział alergenów w prowokowaniu zmian skórnych jest bardzo różny u poszczególnych pacjentów. Alergia pokarmowa jest przeceniana szczególnie przez pediatrów, występuje w mniejszości przypadków, zwykle u małych dzieci z ciężkim przebiegiem wyprysku. Dlatego też narażanie dzieci na niedobory pokarmowe wskutek stosowania diet eliminacyjnych jest w wielu przypadkach zbędne. W wykładzie omówiono również różne poglądy na temat sensu leczenia antybiotykami pacjentów $\mathrm{z}$ atopowym zapaleniem skóry $\mathrm{w}$ aspekcie kolonizacji skóry gronkowcem złocistym. Po raz kolejny usłyszeliśmy również o problemie uczulenia na emolienty u chorych z atopią. Kolejnym punktem tej sesji był wykład „Skóra atopowa”. Profesor Roman Nowicki przedstawił $\mathrm{w}$ nim problem trudności współpracy lekarz-pacjent w leczeniu chorego $\mathrm{z}$ atopią i podkreślił rolę dermatologa $\mathrm{w}$ rozpoznawaniu atopowego zapalenia skóry. Bardzo ważne było zaakcentowanie istotnego znaczenia terapii podstawowej (edukacja, unikanie alergenów i związków drażniących oraz emolienty) w uzyskaniu i podtrzymaniu remisji zmian skórnych. Niezależnie od cennych i od dawna stosowanych składników emolientów, poznaliśmy nowe, takie jak likochalkon - flawonoid zawarty w wyciągu z lukrecji - czy wytwarzana przez ekstremolity ektoina. Na zakończenie tej sesji dr Magdalena Trzeciak z gdańskiej Kliniki Dermatologicznej przedstawiła $\mathrm{w}$ formie quizu interaktywnego 11 różnych przypadków klinicznych, a uczestnicy konferencji mieli okazję sprawdzić swoją wiedzę dermatologiczną.

Wieczorna, V sesja pierwszego dnia konferencji była poświęcona mikologii. W pierwszym wykładzie doc. Anita Hryncewicz-Gwóźdź z Wrocławia przedstawiła możliwości diagnostyczne zakażeń grzybiczych skóry i błon śluzowych. Złotym standardem nadal pozostaje badanie bezpośrednie i hodowla. Aktualnie mamy do czynienia $\mathrm{z}$ intensywnym rozwojem molekularnej diagnostyki mikologicznej (sekwencjonowanie DNA, PCR, RFLP, RAPD), która cechuje się wysoką czułością oraz swoistością i w chwili obecnej służy przede wszystkim do identyfikacji i różnicowania gatunków grzybów. Trwają natomiast badania nad możliwością wykonywania prostych testów służących do rutynowej diagnostyki. Drugi wykład w tej sesji, poświęcony grzybicy paznokci, przedstawił prof. Roman Nowicki. Wykład był bogato ilustrowany przypadkami klinicznymi. Obrazy dotyczyły nie tylko zmian grzybiczych, lecz także zmian w płytkach paznokciowych w przebiegu różnych schorzeń. Przedstawione dane wskazują na stały wzrost zachorowań na grzybicę paznokci w Polsce i na świecie. Czynnikami etiologicznymi są najczęściej dermatofity, a ponadto grzyby drożdżopodobne oraz pleśnie. W przypadku tych ostatnich, szczególnie infekcji Scopulariopsis brevicaulis, zmiany źle reagują na leczenie antymikotyczne i niekiedy jedyną metodą terapii jest usunięcie chirurgiczne zmienionych płytek. Istnieje wiele czynników predysponujacych do rozwoju grzybicy paznokci, w tym przede wszystkim choroby ogólnoustrojowe, leczenie immunosupresyjne czy niewłaściwe (okluzyjne) obuwie. Na zakończenie tej sesji odbył się quiz interaktywny. Dzięki niemu wszystkie osoby uczestniczące w sesji miały okazję przekonać się, że $\mathrm{z}$ powodu bardzo różnorodnego charakteru zmian na skórze i w płytkach paznokciowych, które mogą imitować grzybicę, w każdym przypadku istnieje konieczność weryfikacji rozpoznania badaniem mikologicznym.

Po intensywnym dniu obrad, w godzinach wieczornych, uczestnicy konferencji spotkali się na uroczystej kolacji, w której programie, oprócz wyśmienitej kuchni i znakomitej muzyki, był także wykład gospodarza spotkania prof. Romana Nowickiego na temat suplementacji cynkiem i witaminą A w profilaktyce i leczeniu chorób skóry.

W drugim dniu obrad konferencji, po warsztatach "Terapia podstawowa AZS, mokre opatrunki", o godzinie 10.00 rozpoczęła się sesja "Dermatoonkologia". Tematem pierwszego wykładu, wygłoszonego przez dr Annę Kowalczyk z Kliniki Onkologii i Radioterapii GUM, była diagnostyka i leczenie czerniaka. Prelegentka przedstawiła metody terapii tego złośliwego nowotworu na pod- 
stawie najnowszych danych $\mathrm{z}$ piśmiennictwa i doświadczeń własnych. Metodą z wyboru ciągle jest usunięcie chirurgiczne ogniska pierwotnego z marginesem skóry zdrowej. W postaciach zaawansowanych i rozsianych stosowane są metody alternatywne (IFN2- $\alpha$, radioterapia, chemioterapia dekarbazyną). Nie wydłużają one jednak czasu całkowitego przeżycia chorych. Przełomem dla tej grupy chorych był rok 2010, kiedy zastosowano po raz pierwszy immunoterapię, wprowadzając do leczenia przeciwciało monoklonalne przeciwko CTLA4 (ipilimumab), które pozwala na uzyskanie długoletnich przeżyć u części chorych. Oprócz immunoterapii istnieje już możliwość zastosowania leków celowanych molekularnie, do których należy wemurafenib - inhibitor kinazy tyrozynowej. W kolejnym wykładzie tej sesji doc. Magdalena Lange z Kliniki Dermatologicznej GUM przedstawiła nowe możliwości diagnostyki i leczenia mastocytozy na podstawie najnowszego konsensusu europejskiego. Ze względu na heterogenny obraz kliniczny rozpoznanie tego rzadkiego schorzenia jest trudne. Wybór metody leczenia zależy od postaci choroby i stwierdzanych objawów. W przypadkach mastocytozy układowej o ciężkim przebiegu możliwe jest zastosowanie terapii cytoredukcyjnej, alogenicznego przeszczepu szpiku, splenektomii czy terapii celowanej na podstawie wyników badań genetycznych. W leczeniu objawów zależnych od wydzielania mediatorów, obok wcześniej stosowanych preparatów, skuteczny okazał się omalizumab. Trzeci wykład, doc. Małgorzaty Sokołowskiej-Wojdyło z Kliniki Dermatologicznej w Gdańsku, dotyczył coraz powszechniejszego problemu onkologicznego w dermatologii, jakim są chłoniaki skóry. Dzięki bardzo bogatej prezentacji przypadków klinicznych mieliśmy możliwość poznania różnorodnego obrazu klinicznego chłoniaków wywodzących się pierwotnie ze skóry, które szczególnie w pierwszej fazie mogą imitować różne schorzenia zapalne. W zależności od rodzaju chłoniaka pomyłki diagnostyczne mogą dotyczyć takich chorób, jak granulomatosis cum polyangiitis (ziarniniak Wegenera), głęboka postać tocznia rumieniowatego czy sarkoidoza. W celu właściwej diagnostyki niezbędna jest współpraca dermatologa z onkologiem i internistą, a niekiedy również z pediatrą - ze względu na pojawiające się w ostatnim czasie przypadki chłoniaków w coraz młodszych grupach wiekowych. Na zakończenie tej sesji wykład dotyczący powikłań skórnych po leczeniu onkologicznym przedstawił prof. Witold Owczarek, kierownik Kliniki Dermatologii CSK MON w Wojskowym Instytucie Medycznym w Warszawie. Zwrócił uwage na różne mechanizmy powstawania zmian skórnych po preparatach stosownych w terapii nowotworów. Objawy te mogą być związane $\mathrm{z}$ nad- wrażliwością na lek, ze zmniejszoną odpornością lub z nasileniem wcześniej istniejących zmian skórnych. Najwięcej miejsca w wykładzie poświęcono zasadom profilaktyki, monitorowania i leczenia zmian trądzikopodobnych wywołanych przez inhibitory naskórkowego czynnika wzrostu (ang. epidermal growth factor receptor - EGFR) oraz zmian po stosowaniu inhibitora BRAF (nadwrażliwość na światło, osutki plamisto-grudkowe, zaburzenia rogowacenia oraz nowotwory łagodne i złośliwe).

Sesja VII poświęcona była barierze naskórkowej. Profesor Cezary Kowalewski przedstawił wykład dotyczący patomechanizmu uszkodzenia bariery naskórkowej w atopowym zapaleniu skóry i możliwości jej naprawy. Jednym z czynników odpowiedzialnych za to uszkodzenie jest wrodzony lub nabyty niedobór filagryny. Konsekwencją tego defektu naskórkowego jest przede wszystkim wyprysk atopowy. Istnieją również badania sugerujące, że wskutek wzmożonego wnikania alergenów powietrznopochodnych przez uszkodzoną barierę naskórkową może dochodzić do wzrostu zapadalności na astmę. W tym kontekście stosowanie emolientów nabiera szczególnego znaczenia, nie tylko jako preparatów nawilżających i natłuszczających skórę, ale czynników mogących zatrzymać rozwój marszu alergicznego.

Sesja VIII dotyczyła chorób przenoszonych drogą płciową, a także schorzeń umiejscowionych w obrębie narządów płciowych. Doktor Igor Michajłowski z gdańskiej Kliniki Dermatologicznej przedstawił przydatną z praktycznego punku widzenia klasyfikację dermatoz zewnętrznych narządów płciowych ze szczególnym uwzględnieniem trzech jednostek chorobowych: liszaja płaskiego, liszaja twardzinowego oraz liszaja zwykłego przewlekłego, które stwarzają największe trudności diagnostyczno-terapeutyczne. Dla optymalnego efektu leczniczego niezbędna jest dobra współpraca różnych specjalistów (dermatologów, urologów i ginekologów), u których szukają pomocy pacjenci z tymi schorzeniami. W drugim wykładzie doc. Agnieszki Serwin i dr Marty Koper z Kliniki Dermatologii i Wenerologii Uniwersytetu Medycznego w Białymstoku usłyszeliśmy o najnowszych europejskich zaleceniach diagnostycznych i leczniczych w rzeżączce i nierzeżączkowych zakażeniach dróg moczowo-płciowych (ang. non gonococcal uretritis - NGU). W zaleceniach podkreśla się znaczenie hodowli oraz metod molekularnych w diagnostyce rzeżączki. Ze względu na oporność dwoinek rzeżączki na cyprofloksacynę, tetracyklinę, penicylinę i azytromycynę, zgodnie z aktualnymi wytycznymi europejskimi, zaleca się leczenie niepowikłanej rzeżączki ceftriaksonem (500 mg domięśniowo) z azytromycyną (2 g doustnie). Głównymi czynnikami etiologicznymi NGU są Chlamydia 
trachomatis i Mycoplasma genitalium. W diagnostyce zakażeń chlamydialnych powinny być stosowane wyłącznie metody molekularne wykrywające materiał genetyczny (plazmid, MOMP, rRNA). W leczeniu NGU wywołanych przez $C$. trachomatis rekomendowana jest azytromycyna (pojedyncza dawka $1 \mathrm{~g}$ ) lub doksycyklina (kuracja 7-dniowa w dawce 200 mg/ dobę). W leczeniu przewlekłych lub nawrotowych NGU, które zazwyczaj mają etiologię wieloczynnikową, stosuje się azytromycynę łącznie z metronidazolem. W wykładzie podkreślono, że rzeżączka i nierzeżączkowe zakażenia dróg moczowych stanowią istotny problem epidemiologiczny w skali globalnej. Niewłaściwie rozpoznane i źle leczone mogą prowadzić do wielu powikłań, dlatego też istnieje potrzeba poprawy diagnostyki tych zakażeń oraz nadzoru epidemiologicznego $\mathrm{w}$ tym zakresie.

Na zakończenie konferencji, w sesji IX „Nefrolodzy dla dermatologów" usłyszeliśmy wykład "Zastosowanie cyklosporyny w dermatologii" doc. Teresy Bączkowskiej z Kliniki Medycyny Transplantacyjnej i Nefrologii Warszawskiego Uniwersytetu Medycznego. Prelegentka przedstawiła zasady bezpiecznej terapii cyklosporyną. Ze względu na wąski indeks terapeutyczny i osobniczą reakcję na lek bardzo istotne jest monitorowanie leczenia. Zaleca się obserwację kliniczną oraz badanie stężenia leku w surowicy (2 godziny od przyjęcia). Z uwagi na liczne interakcje cyklosporyny bardzo ważny jest skrupulatny wywiad dotyczący innych leków stosowanych przez pacjenta.

Wszystkie wykłady cieszyły się bardzo dużym zainteresowaniem uczestników, o czym świadczyła bardzo dobra frekwencja w trakcie trwania całej kon-



Rycina 4. Pełna sala w czasie trwania konferencji

ferencji pomimo pięknej, letniej pogody, która towarzyszyła obradom (ryc. 4.).

Interaktywna forma prezentacji z wykorzystaniem systemu do głosowania, analiza odpowiedzi oraz możliwość zadawania pytań wykładowcom - ekspertom pozwoliły na wyjaśnienie najistotniejszych i najtrudniejszych problemów. Program naukowy konferencji był bardzo bogaty, dlatego też na podziwianie piękna Sopotu pozostały jedynie godziny późnowieczorne i nocne.

Kolejna konferencja „Dermatologia, Wenerologia i Alergologia 2015" połączona z jubileuszem 70-lecia Kliniki Dermatologicznej w Gdańsku rozpocznie się w czwartek, 22 października 2015 roku. Zapraszamy!

Elżbieta Grubska-Suchanek Klinika Dermatologii, Wenerologii i Alergologii Gdańskiego Uniwersytetu Medycznego 